\title{
PREVENTION AND TREATMENT OF MUCOSITIS AT AN ONCOLOGY OUTPATIENT CLINIC: A COLLECTIVE CONSTRUCTION
}

\author{
Livia Dantas Lopes ${ }^{1}$, Andrea Bezerra Rodrigues², Débora Rabelo Magalhães Brasil ${ }^{3}$, Maysa Mayran Chaves \\ Moreira ${ }^{4}$ Juliana Gimenez Amaral ${ }^{5}$, Patrícia Peres de Oliveira ${ }^{6}$
}

${ }^{1}$ Nursing Resident. Integrated Multiprofessional Residency in Hospital-Based Health Care. Universidade Federal do Ceará (UFC).
Fortaleza, CE, Brazil. E-mail: 1_dlopes@hotmail.com
2 Ph.D. in Nursing. Adjunct Professor at UFC. Fortaleza, Ceará, Brazil. E-mail: andreabrodrigues@gmail.com
${ }^{3}$ Master's student in Health Promotion. Graduate Nursing Program at UFC. Fortaleza, Ceará, Brazil. E-mail: debbora_maggalhaes@
hotmail.com
${ }^{4}$ Oncology Nursing Resident. Multiprofessional Residency, Instituto do Câncer do Ceará. Fortaleza, Ceará, Brazil. E-mail: maysa.
enfa.ufc@hotmail.com
${ }^{5}$ Doctoral student, Graduate Program in Environmental and Experimental Pathology at Universidade Paulista (UNIP). Professor
at UNIP. São Paulo, São Paulo, Brazil. E-mail: amaral_ju@yahoo.com.br
${ }^{6}$ Ph.D. in Education. Adjunct Professor, Universidade Federal de São João del-Rei. Divinópolis, Minas Gerais, Brazil. E-mail:
pperesoliveira@gmail.com

\begin{abstract}
The aim was to develop a nursing care protocol for the prevention and treatment of chemotherapy-induced mucositis at an outpatient clinic of a High Complexity Center in Oncology. A qualitative convergent-care research was undertaken. The construction of the protocol was driven by the criteria of Evidence-Based Practice. Data were collected from January to June 2013 in two steps. Firstly, we collected data on medical charts of customers to obtain sociodemographic and therapeutic data and nursing interventions performed for prevention, detection and treatment of mucositis. After this first step, workshops were held with the nurses to validate the available material and human resources, besides the feasible care to compose the protocol. Care was related to oral hygiene, mouth rinse, cryotherapy, laser therapy and interventions related to the nutritional scope. The implementation of this care protocol has standardized the care strategies.

DESCRIPTORS: Oncologic nursing. Chemotherapy. Mucositis. Nursing care.
\end{abstract}

\section{PREVENÇÃO E TRATAMENTO DA MUCOSITE EM AMBULATÓRIO DE ONCOLOGY: UMA CONSTRUÇÃO COLETIVA}

RESUMO: Objetivou-se elaborar um protocolo assistencial de enfermagem para prevenção e tratamento da mucosite induzida por quimioterapia em um ambulatório de um Centro de Alta Complexidade em Oncologia. Pesquisa qualitativa do tipo Convergente-Assistencial. A construção do protocolo foi norteada pelos critérios da Prática Baseada em Evidências. A coleta de dados foi realizada no período de janeiro a junho de 2013 em duas etapas. Inicialmente, foram coletados dados nos prontuários dos clientes, com a finalidade de conhecer dados sociodemográficos e terapêuticos e intervenções de enfermagem realizadas para prevenção, detecção e tratamento da mucosite. Após essa primeira etapa, procedeuse à realização de oficinas com as enfermeiras, com vistas à validação dos recursos materiais e humanos disponíveis, além dos cuidados viáveis para compor o protocolo. Emergiram cuidados relacionados à higiene oral, enxágue bucal, crioterapia, terapia a laser e intervenções relacionadas ao âmbito nutricional. A implementação desse protocolo de cuidados padronizou estratégias de cuidado.

DESCRITORES: Enfermagem oncológica. Quimioterapia. Mucosite. Cuidados de enfermagem.

\section{PREVENCIÓN Y TRATAMIENTO DE LA MUCOSITIS EN AMBULATORIO DE ONCOLOGÍA: UNA CONSTRUCCIÓN COLECTIVA}

RESUMEN: El objetivo fue elaborar un protocolo asistencial de enfermería para prevención y tratamiento de la mucositis inducida por quimioterapia en un ambulatorio de un Centro de Alta Complejidad en Oncología. Investigación cualitativa del tipo ConvergenteAsistencial. La construcción del protocolo fue orientada por los criterios de la Práctica Basada en Evidencias. La recopilación de datos fue realizada en el periodo de enero a junio de 2013 en dos etapas. Inicialmente, recopilamos datos en los historiales médicos de los clientes, con el fin de conocer datos sociodemográficos y terapéuticos e intervenciones de enfermería para prevención, detección y tratamiento de la mucositis. Después de esta primera etapa, se procedió a la realización de talleres con las enfermeras, con miras a la validación de los recursos materiales y humanos disponibles, además de los cuidados razonables para componer el protocolo. Han surgido cuidados relacionados con la higiene oral, enjuague bucal, crioterapia, terapia láser y intervenciones relacionadas con el ámbito nutricional. La implementación de este protocolo de cuidados estandarizó las estrategias de cuidado.

DESCRIPTORES: Enfermería oncológica. Quimioterapia. Mucositis. Cuidados de enfermería. 


\section{INTRODUCTION}

Antineoplastic chemotherapy is a widely used treatment form of cancer in different anatomic sites. ${ }^{1}$ These drugs cause collateral effects in different organic systems, including the gastrointestinal system. Nausea, vomiting, lack of appetite and mucositis are the most common collateral effects in this system. ${ }^{2-5}$ Mucositis is defined as inflammatory lesions and/or ulcers in the oral and/or gastrointestinal tract, resulting in severe discomfort that can impair the patients' ability to eat, swallow and talk. ${ }^{3}$

Besides these changes, it can also cause dry mouth, which in turn predisposes to secondary infections, mainly by fungi. Other possible consequences are changes in the sense of taste, leading to low fluid and food intake, dehydration and malnutrition. The pain cannot be ignored, for chewing as well as swallowing, as the inflammation process can occur all over the digestive tract, as well the increased risk of local and systemic infection. ${ }^{5}$ The bleeding can also appear when the mucositis is more advanced. Severe cases may demand hospitalization for enteral or parenteral nutritional support, and even postponement or suspension of the antineoplastic treatment. ${ }^{6}$

The incidence of mucositis for people with head and neck cancer undergoing radition therapy associated with chemotherapy amounts to approximately $85 \%$, but all individuals treated present some level of oral mucositis. This is one of the main limiting factors of chemoradiation for advanced head and neck tumors. For people submitted to bone marrow transplantation, the incidence reaches $75 \%$. Data on all tumor sites treated with high doses of antineoplastic drugs lead to high levels of mucositis (between 20 and 50\%). ${ }^{5}$

Mucositis can be classified in four levels. The first level is only characterized by the presence of erythema; the second by the appearance of white desquamatory plaques painful to touch; the third level is characterized by the appearance of epithelial crusts and fibrinous exsudate, leading to the formation of pseudomembranes and ulcerations. The fourth level is the most severe form of mucositis, and occurs when stroma is exposed in the underlying conjuntive tissue. . $^{2-3,6-7}$

There are ways to prevent or reduce the intensity of the mucositis. These include oral hygiene, rinsing using appropriate mouthwash, lip lubrication, appropriate nutrition, xerostomy control, cryo- therapy, use of low-potency laser and suspension of substances and foods irritating to the mucosa, such as tobacco. ${ }^{7-8}$

Therefore, appropriate multiprofessional intervention is needed, and this group of professionals includes nurses. The support system for making nursing care planning decisions includes care protocols, which represent a strategy that needs to be elaborated according to the clients' needs and the resources available.

The protocol is a proposal to standardize procedures, which the health professionals can elaborate to guide their practice. The protocols organize and speed up the health services, establishing flows. ${ }^{9}$ The lack of standardization of the actions causes weakness, which may lead to great variation in the ways the actions are executed.

Nevertheless, implementing the protocols in care practice represents a challenge. Studies recommend dynamic protocols, put in practice in cooperation with the health professionals with a view to motivating all stakeholders, permitting the continuing assessment of care delivery and the creation of effective therapeutic objectives. ${ }^{9-10}$ Elaborating and implementing a protocol can reduce the institution's costs, mitigate the team's stress during the client's treatment period and contributing to a better quality of care. ${ }^{11}$

In that context, to develop effective interactions for the prevention and treatment of mucositis induced by antineoplastic treatment, the following question emerged: what care is relevant to be included in a care protocol for clients who will receive antineoplastic chemotherapy treatment, with potential to cause mucositis, at a high-complexity oncology center?

To answer this question, the following objective was outlined: elaborate a nursing care protocol to prevent and treat the chemotherapy-induced mucositis at an outpatient clinic of a High-Complexity Oncology Center.

\section{METHOD}

A qualitative convergent-care research (CCR) was undertaken, a method acknowledged as the explicit acknowledgement of practice with emphasis on intersubjectivity and dialogue in the research process as a practice of reality. The CCR is based on a practical situation and, hence, goes directly along with the researcher's proposal. ${ }^{12}$ 
To enhance the research process, the CCR establishes four phases: conception, instrumentation, screening and interpretation. The conception phase includes the definition of the topic, formulation of the research problem, literature review and definition of the theoretical framework. In the instrumentation phase, the place, participants, data collection form and registration of the research data. The screening establishes the strategies and instruments to be used to acquire the information for the study. The analysis phase establishes the interpretation of what was collected. . $^{10,12}$

In the case of this study, the conception phase emerged after a meeting with the coordinator of the chemotherapy outpatient clinic, where the importance of standardizing some nursing interventions was highlighted in view of problems the clients experienced. One of these problems identified was related to preventive care and treatment for mucositis. From that point onwards, an agreement was reached with the nurses to jointly elaborate a care protocol for the prevention and treatment of chemotherapy-induced mucositis.

Thus, the study context was an outpatient clinic of a High-Complexity Oncology Center (Cacon), located in the state of Ceará, which attended about 2,000 patients per month. The health team consisted of eight physicians, one nutritionist, one pharmacist and one dentist (the latter at a referral hospital), two nursing technicians and six nurses, two of whom were nursing residents, that is, they were taking a lato sensu specialization program. It is highlighted that the above institution had no care protocols at the oncology outpatient clinic.

The choice of the participants complied with the following inclusion criterion: being a nurse working at the study sector during the research period. The exclusion criteria included nurses on vacation, on medical leave for health treatment, on maternity leave or on leave of absence for professional training. After complying with these criteria, six nurses were obtained, five of whom were assistant nurses and one was the nursing service coordinator.

The data were collected between January and June 2013. During the screening phase, data were collected on the clients undergoing antineoplastic treatment at the clinic by consulting their histories. Therefore, two tools were constructed, the first to find out about the material and human resources (mouthwash, availability of laser therapy with dentist, assessment of nutritional risk with forwarding to nutritionist, among others), and the nursing interventions for the sake of prevention, detection and treatment of the mucositis. The goal of the second tool was to discover the clients' profile through a script for data collection from the histories regarding the clients' sociodemographic and therapeutic data.

Three nurse experts assessed the topics of these two tools for relevance, clarity and applicability. These professionals should be knowledgeable on the theme, with profiles that complied with the following criteria: be a nurse, with activities proven in a Lattes curriculum (database of Brazilian Council for Scientific and Technological Development) in oncology, with at least ten years of experience, that is: the first expert was a coordinator of a graduate program in oncology located in the city of São Paulo, with 21 years of experience in oncology; the second expert was a nurse coordinator of a chemotherapy outpatient clinic located in the city of São Paulo, with 14 years of experience; and the third was a professor from a federal university with a Ph.D. degree and 17 years of experience in oncology. The experts were also asked to suggest items and any changes they found pertinent.

In total, 105 histories were studied from patients who received antineoplastic drugs between January and June 2013, selected through simple random sampling. Thirty-four of them received chemotherapy with potential to cause mucositis. It should be highlighted that the large majority of the clients to whom antineoplastic drugs were prescribed would receive them at the inpatient service.

Next, two workshops were held at a private room in the study context, involving the nurses and the responsible researcher, with a view to validating the material and human resources available and the care feasible for inclusion in the mucositis prevention and treatment protocol, in order to include interventions that considered the cost, easy implementation, availability of material and compliance with these measures. The workshops were held according to the participants' preference and availability.

The first workshop was aimed at collecting information from each nurse about what nursing care was provided for the prevention and treatment of mucositis, also discussing the intervention options for inclusion in the nursing care protocol, based on 
the data surveyed in the histories and the individual experience gained during work. Twenty-three care actions emerged for the prevention and treatment of chemotherapy-induced mucositis, which were analyzed in view of the Evidence-Based Practice (EBP) criteria, corresponding to the initial phase of the theorization.

In EBP, the evidence levels are organized according to classification systems. In this study, the classification ${ }^{13}$ was adopted that organizes the evidence levels into: level 1 - evidence from systematic review or meta-analysis of all relevant randomized controlled clinical trials or from clinical guidelines based on randomized controlled clinical trials; level 2 - evidence deriving from at least one well-designed randomized controlled clinical trial; level 3 - evidence from well-designed randomized clinical trials without randomization; level 4 - evidence form well-designed cohort and case-control studies; level 5 - evidence from systematic review of descriptive and qualitative studies; level 6 - evidence from a single descriptive or qualitative study; level 7 - evidence from expert opinions and/or expert committee reports. ${ }^{13}$

The second workshop was aimed at discussing the material found. After group reflection, the care actions were grouped in categories and organized according to the evidence levels, producing an algorithm to approach patients undergoing chemotherapy and the mucositis prevention and treatment protocol, considering the feasibility of these practices in the study context.

For the analysis and interpretation of the data, the framework by Morse and Field ${ }^{14}$ was adopted, recommended by the developers of the CCR method, ${ }^{12}$ which includes four phases: collection, synthesis, theorization and recontextualization. In the analysis phase, the collection process was undertaken, including the collection and organization of the information based on the two jointly elaborated tools and the first workshop.

The synthesis included the study of the collected information, analyzing the associations and variations. Finally, the recontextualization corresponded to the final phase of the theorization, permitting the creation of the algorithm and resulting in the protocol for the prevention and treatment of chemotherapy-induced mucositis.

Approval for the study was obtained from the Research Ethics Committee at Universidade Federal do Ceará, under protocol 459.842/12. The research participants voluntarily accepted the invitation to participate in the study, signing a Free and Informed Consent Form, in compliance with National Health Council resolution 466/2012.15

\section{RESULTS AND DISCUSSION}

Based on the first tool, the nurses and the researchers could verify that the institution had the following material resources for oral rinsing: bicarbonate water, chlorhexidine gluconate, benzydamine hydrochloride, chlorhexidine digluconate associated with sodium fluoride and nystatin. Head and neck cancer patients were forwarded for a dental appointment at another institution. In case of severe mucositis, the antineoplastic treatment was generally suspended, a nasogastric tube was installed and the client was forwarded for hospitalization. They also found that the nursing consultation had not been put in practice and that orientations to prevent mucositis were not provided, but merely when the person was already suffering from mucositis. If that was the case, patients were advised to do oral rinsing with mouthwash and lip lubrication using cacao butter.

Through the second tool, the participants could get to know the clients who received antineoplastic treatment with potential to cause mucositis. During the study period, the majority was female, with a mean age of 52.9 years, from the state capital, married, with a family income of two to four minimum wages and incomplete primary education. The most incident anatomic topographies of cancer were breast, reproductive and gastrointestinal systems and the most used antineoplastic drugs were: cyclophosphamide, doxorubicin, paclitaxel and 5-fluorouracil (5-FU). After the information collected from the participants had been presented during the first workshop, the nurses reflected on their daily life at the outpatient service, which permitted the elaboration of 23 care actions to prevent and treat the chemotherapy-induced mucositis. The choice of the actions was evidence-based and considered the feasibility of their application at the service.

Figure 1 displays the algorithm of the care protocol for clients submitted to antineoplastic chemotherapy, using drugs with potential to cause mucositis. 


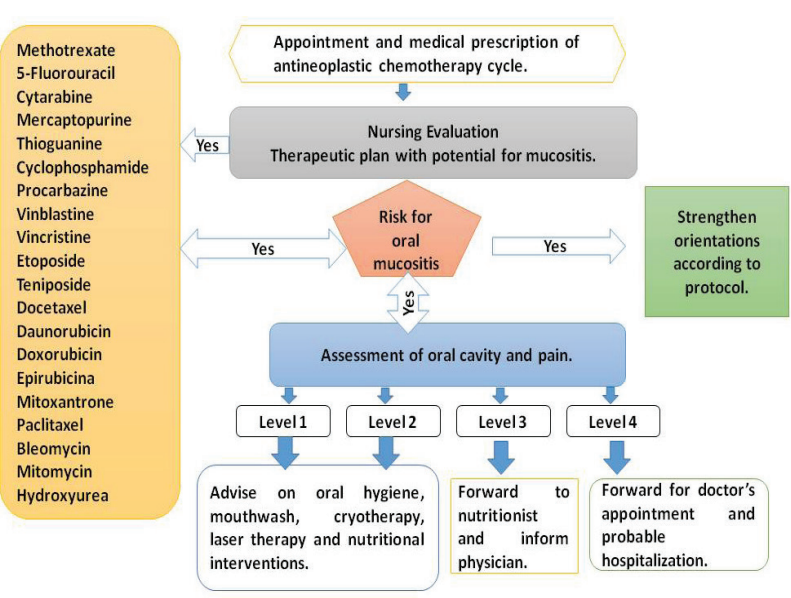

Figure 1 - Algorithm of care protocol for client submitted to antineoplastic chemotherapy treatment with potential to cause mucositis. Fortaleza, Ceará, 2013

The following objectives of the protocol were determined: guarantee oral cavity evaluation by nurses for all clients who used antineoplastic drugs with potential to cause mucositis, using the Common Terminology Criteria for Adverse Events (CTCAE $)^{16}$ version 4 , which the nurse manager from the consultation service should make available; identify the additional risk factors for mucositis, such as smoking, alcohol use, dental prostheses, oral injuries; implement pain assessment at each chemotherapy cycle, using a numerical analogue or faces scale (in case of cognitive impairment or elderly clients) $;{ }^{17}$ define the role of the professionals on the nursing care team in terms of records on mucositis and pain assessment treatment and reassessment; guide nursing team training on mucositis assessment and management regarding antineoplastic drugs and guarantee advice by the nursing team for clients and companions on mucositis prevention/ risk reduction and treatment forms.

In this protocol, nurses will assess the oral cavity and additional risk factors for the development of mucositis in clients submitted to antineoplastic drugs with potential to cause mucositis, using the CTCAE scale. The nurse should display on the notice board of the outpatient clinic a list with the drugs that can cause mucositis for advice and consultation. Even if the client does not have mucositis, the nursing assessment has to be repeated at each new chemotherapy cycle. The professional registers the presence or absence of pain and its intensity in the patient history. In case of pain, the patient's physician is contacted for pain management.

The mucositis evaluation descriptions should mention the degree of mucositis and functional changes in accordance with the CTCAE scale. Concerning the pain, besides the intensity, the duration, periodicity and factors that improve and worsen the pain should be mentioned. For clients receiving the first chemotherapy cycle, the orientations provided according to the protocol should be registered in the patient history. As from the second cycle, the orientations provided/changed and the patient's compliance should be registered in the history, together with the respective motives, as well as any refusal by the patient to follow orientations.

Thus, care actions for the prevention and treatment of mucositis induced by antineoplastic chemotherapy, grouped in categories as established by the research participants and organized with their respective evidence levels, are displayed in Table 1.

Table 1 - Categories, care related to prevention and treatment of antineoplastic chemotherapy-induced mucositis and evidence level of care. Fortaleza, Ceará, 2013

\begin{tabular}{|l|l|c|}
\hline \multirow{5}{*}{ Categories } & $\begin{array}{l}\text { Care related to the prevention and treatment of antineoplastic chemotherapy-induced } \\
\text { mucositis }\end{array}$ & $\begin{array}{c}\text { Evidence } \\
\text { level }\end{array}$ \\
\hline \multirow{5}{*}{ Oral hygiene } & Establish a tooth brushing routine using a small and soft brush. & Level III \\
\cline { 2 - 3 } & Brush tongue delicately (for prevention only, i.e. without installed mucositis). & Level III \\
\cline { 2 - 3 } & Floss whenever possible (will depend on blood count result and oral mucosa assessment). & Level III \\
\cline { 2 - 3 } & Use non-abrasive toothpaste, preferably containing baking soda and/or fluoride. & Level V \\
\cline { 2 - 3 } & Tooth brushing after meals and before going to bed. & Level III \\
\cline { 2 - 3 } & Remove dental prostheses and wash them 30 minutes after meals and at night. & Level III \\
\cline { 2 - 3 } & Assess the evolution of the injuries and advise on oral hygiene maintenance. & Level III \\
\cline { 2 - 3 } & Maintain oral hygiene, only avoiding tongue brushing (in case of installed mucositis). & Level III \\
\cline { 2 - 3 } & Suspend use of dental prostheses (if these exist) in case of oral mucosa injuries. & Level III \\
\cline { 2 - 3 } & $\begin{array}{l}\text { Put a piece of gauze around the finger for oral hygiene if the patient feels pain and is unable } \\
\text { to brush. }\end{array}$ & Level VII \\
\hline
\end{tabular}




\begin{tabular}{|c|c|c|}
\hline Categories & $\begin{array}{l}\text { Care related to the prevention and treatment of antineoplastic chemotherapy-induced } \\
\text { mucositis }\end{array}$ & $\begin{array}{c}\text { Evidence } \\
\text { level }\end{array}$ \\
\hline \multirow{3}{*}{ Mouthwash } & $\begin{array}{l}\text { Rinse with } 0.9 \% \text { saline solution or } 3 \% \text { water with baking soda, } 4 \text { to } 6 \text { times per day. If the } \\
\text { patient cannot buy mouthwash, the institution can provide it, as it is available nowadays. }\end{array}$ & Level V \\
\hline & $\begin{array}{l}\text { Advise on rinsing with } 2 \% \text { morphine solution to treat the pain due to oral mucositis in cli- } \\
\text { ents, patients will receive chemoradiation for head and neck cancer. }\end{array}$ & Level III \\
\hline & $\begin{array}{l}\text { Advise not to use antimicrobial mouthwash to prevent oral mucositis in clients who will } \\
\text { receive high doses of chemotherapy or in people who will receive concomitant radiation } \\
\text { therapy or chemotherapy for head and neck cancer. }\end{array}$ & Level II \\
\hline \multirow[t]{2}{*}{ Cryotherapy } & $\begin{array}{l}\text { Forwarding for oral cryotherapy can be used to prevent oral mucositis in patients who re- } \\
\text { ceived a high dose of melphalan, with or without full body radiation, as the conditioning for } \\
\text { the transplantation. }\end{array}$ & Level III \\
\hline & $\begin{array}{l}\text { Forward for } 30 \text { minutes of oral cryotherapy used to prevent oral mucositis in clients who } \\
\text { received intravenous chemotherapy in a bolus of 5-fluorouracil. }\end{array}$ & Level II \\
\hline $\begin{array}{c}\text { Laser } \\
\text { therapy }\end{array}$ & $\begin{array}{l}\text { Forward for laser } 40 \mathrm{~mW} \text { to prevent oral mucositis in clients who will receive bone marrow } \\
\text { transplantation, conditioned with high doses of chemotherapy. }\end{array}$ & Level II \\
\hline \multirow{7}{*}{$\begin{array}{c}\text { Nutritional } \\
\text { interventions }\end{array}$} & Consume foods cold or at room temperature, including jelly and non-acid fruit sorbets. & Level V \\
\hline & $\begin{array}{l}\text { Avoids foods that irritate the oral mucosa, such as citric juice, spicy or very salty and coarse } \\
\text { and dry foods }\end{array}$ & Level V \\
\hline & $\begin{array}{l}\text { Consume foods that are easy to chew and swallow, in the form of mashes and creams, in- } \\
\text { cluding bananas and other soft fruits; and fruits rich in liquid, such as watermelon. }\end{array}$ & Level V \\
\hline & Cook food until soft and mild. & Level V \\
\hline & $\begin{array}{l}\text { Increase fluid intake, as well as fluid content of foods, adding meat sauce, meat stock, or non- } \\
\text { spicy sauces. }\end{array}$ & Level IV \\
\hline & $\begin{array}{l}\text { Forward the client for monitoring with nutritionist with respective evaluation records of } \\
\text { mucositis, certifying inability to consume foods and fluids orally. }\end{array}$ & Level II \\
\hline & $\begin{array}{l}\text { Contact physician about client's situation and require assessment for possible placement of } \\
\text { nasoenteral probe. }\end{array}$ & Level II \\
\hline
\end{tabular}

Next, based on the literature, the care will be discussed that was listed for inclusion in the prevention and treatment protocol of antineoplastic chemotherapy-induced mucositis.

\section{Oral hygiene}

Appropriate hygiene of the antineoplastic chemotherapy patients' oral cavity is fundamental, as the results of most studies that have examined the use of oral hygiene protocols to prevent oral mucositis showed beneficial effects. These protocols included a combination of brushing, use of dental floss and mouthwash to maintain oral hygiene. ${ }^{4,6}$ Studies appoint that, independently of the mucositis classification, oral hygiene is fundamental to reduce the influence of the oral bacterial flora, pain symptoms and bleedings related to the antineoplastic therapy. ${ }^{6-7,17-19}$

In the protocol, due to consistent recommendations in the literature and which could be established at the place of study, a tooth brushing routine was determined, using a small and soft brush (child toothbrush), making very short horizontal movements, turning the bristles at least ten times in each region, on the upper as well as lower teeth and external and internal surfaces. ${ }^{20-22}$ Delicate brushing of the tongue should be stimulated. The non-abrasive toothpaste should preferably contain fluor. ${ }^{2,4}$ Brushing should be done 30 minutes after meals and before lying down. Dental prostheses should be removed and washed 30 minutes after meals and at night. ${ }^{5}$

In case of level 3 and 4 mucositis, the patient generally feels pain and is unable to brush. In those cases, the client is instructed to wrap his finger in gauze for washing with solution (3\% bicarbonate water or $0.9 \%$ saline solution), four to six times per day. ${ }^{5-6}$

\section{Oral rinsing}

Another intervention indicated to prevent chemotherapy-induced oral mucositis that is associated with oral hygiene is oral rinsing. Some optional solutions are indicated, but none with sufficient evidence level to recommend any product. Nevertheless, some studies favorable appoint mouthwash, which do not require high technology, are easy to apply in care practice and can contribute to improve the quality of life of patients suffering from this problem. ${ }^{6,19,23}$ 
One of the drugs used for mouthwash with antimicrobial activity is $0.12 \%$ chlorhexidine digluconate. It acts in the general disorganization of the microbial cell membrane, inhibiting its specific enzymes. Nevertheless, due the existence of collateral effects like changes in the color of the teeth, increased supragingival calculus and taste changes, its extended use has been contraindicated. ${ }^{6,24}$ Although $0.12 \%$ chlorhexidine digluconate is not effective to prevent oral mucositis, its antimicrobial action permits reducing the severity of the lesions, making the clients feel more comfortable and avoiding interruptions in the antineoplastic therapy. ${ }^{24}$ It is highlighted that chlorhexidine digluconate should not be used to prevent oral mucositis in patients who will receive radiation therapy for head and neck cancer. ${ }^{4}$

Oral rinsing using $0.12 \%$ chlorhexidine digluconate can be one option as a topical antimicrobial agents to improve the treatment of oral infections, based on the professionals' cautious judgment. Nevertheless, the use of oral rinsing with $0.9 \%$ saline solution neither irritates the mucosa nor changes the $\mathrm{pH}$ of the saliva, besides having an excellent cost-benefit relation. Bicarbonate creates an alkaline environment that makes it difficult for the bacteria to multiply., ${ }^{4,2}$ Nevertheless, like chlorhexidine digluconate, it can provoke a negative impact on the taste and an unpleasant feeling while used. ${ }^{24}$

No scientific evidence exists to recommend the mouthwash described. It is merely suggested, being based on level III, IV and V studies. ${ }^{4-6,21}$

Due to the lack of considered evidence, no guideline was possible thus far regarding natural agents to prevent and treat chemotherapy-induced mucositis, such as vitamin A and E, aloe vera, chamomile, Chinese herbs, Rhodiola algida, Traumeel®S, Wobe-Mugos enzyme, among others. ${ }^{4,25}$

In view of incongruencies on the most appropriate mouthwash, it was decided to include the following in the protocol: oral rinsing using $0.9 \%$ saline solution or $3 \%$ bicarbonate water, four to six times per day. In case the person is in no financial conditions to buy the mouthwash, the institution will provide it.

\section{Cryotherapy}

The use of ice, cryotherapy, has been widely disseminated in oral mucositis care for cancer patients. This low-cost therapeutic choice is risk-free, highly effective and easy to apply in clinical practice, offers pain relief and can prevent the development of new lesions. ${ }^{20-21}$ This intervention is consistent with the 2014 clinical practice guidelines for care to clients with oral and intestinal mucositis of the Multinational Association of Supportive Care in Cancer and International Society of Oral Oncology (MASCC/ISOO). ${ }^{4}$ Studies prove a consensus on the recommendation to use cryotherapy to prevent oral mucositis in individuals who received 5-fluorouracil. The use of cryotherapy is suggested in people who will receive high doses of melphalan to condition for bone marrow transplantation (BMT). ${ }^{4-5,21}$

\section{Laser therapy}

Helium-Neon 40mW laser therapy is indicated as pretreatment to reduce the severity of mucositis in patients submitted to antineoplastic chemotherapy. ${ }^{22}$ As this type of treatment requires expensive equipment and specialized operators, however, its use is often restricted to a limited number of people. The following was agreed upon in the protocol under analysis: forward for laser therapy, through referral to a dental specialty center, only clients for BMT, i.e. conditioned with high doses of chemotherapy. $2,-5,20-21$

\section{Nutritional interventions}

The pain associated with the oral mucositis and taste changes after chemotherapy and/or radiation therapy can severely compromise the food intake. ${ }^{6}$ In case of established oral mucositis, a diet containing food that is easy to chew and swallow, fluids, low on acid, savory or spiced foods, which is better tolerated than a normal diet.

The following care actions were selected for the protocol in terms of nutritional interventions: consume cold foods or at room temperature, including jellies and non-acid fruit sorbets; avoid foods that irritate the oral mucosa; consume foods easy to chew and swallow, in the form of mashes and creams; including bananas and other soft fruits; cook the food until soft and mild; increase fluid intake and fluid content of the foods, adding meat sauce, beef stock or non-spicy sauces; forward the client for nutritional monitoring with respective records of mucositis assessment, confirming the inability to consume oral foods and fluids; and contact the physician about the client's situation and demand an evaluation for the possible placement of a nasogastric tube. 


\section{FINAL CONSIDERATIONS}

The profile analysis of the patients who receive antineoplastic outpatient treatment and the institutional resources, in combination with the literature review, permitted the elaboration of the nursing care protocol for the prevention and treatment of mucositis. The goal was to standardize care for these clients for quality purposes. It is highlighted that all nursing professionals participated in the study and that the use of most of the care mentioned is evidence based.

The methodological framework used to elaborate the protocol, which involved the professionals and researchers in all of the process, can be a favorable point for its implementation, as these people served as actors in this construction.

The use of the protocol is expected to be able to contribute to the reduction and prevention of chemotherapy-induced mucosites in the study context. In their activities, the nurses have responsibilities and conducts towards oral mucositis, such as systematic action to monitor the oral cavity and mucositis symptoms, evidence-based nursing intervention planning, always appropriate to the place of their care practice and considering each patient's individual characteristics and needs.

As study limitations, the small sample size of clients submitted to chemotherapy was observed, using drugs with potential to cause mucositis, during the data collection period. Nevertheless, this limitation serves as a guide for the elaboration of future nursing protocols.

\section{REFERENCES}

1. Peck-Radosavljevic M. Drug therapy for advancedstage liver cancer. Liver Cancer. 2014 May; 3(2):125-31.

2. Bonassa EMA, Gato MIR. Terapêutica oncológica para enfermeiros e farmacêuticos. $12^{a}$ ed. Rio de Janeiro: Atheneu; 2012.

3. Spolarich AE. Risk management strategies for reducing oral adverse drug events. J Evid Based Dent Pract. 2014 Jun; 14(Suppl):87-94.

4. Lalla RV1, Bowen J, Barasch A, Elting L, Epstein J, Keefe DM, et al. MASCC/ISOO clinical practice guidelines for the management of mucositis secondary to cancer therapy. Cancer. 2014 May; 120(10):1453-61.

5. Peterson DE, Bensadoun RJ, Roila F; ESMO Guidelines Working Group.Management of oral and gastrointestinal mucositis: ESMO Clinical Practice Guidelines. Ann Oncol. 2011 Sep; 22(Suppl 6):vi78-84.
6. Lalla RV, Sonis ST, Peterson DE. Management of oral mucositis in patients who have cancer. Dent Clin North Am. 2008 Jan; 52(1):61-77.

7. Lalla RV, Saunders DP, Peterson DE. Chemotherapy or radiation-induced oral mucositis. Dent Clin North Am. 2014 Apr; 58(2):341-9.

8. Nicolatou-Galitis O, Sarri T, Bowen J, Di Palma M, Kouloulias VE, Niscola P, et al. Systematic review of anti-inflammatory agents for the management of oral mucositis in cancer patients. Support Care Cancer. 2013 Nov; 21(11):3179-89.

9. Schweitzer G, Nascimento ERP, Nascimento KC, Moreira AR, Bertoncello KCG. Protocolo de cuidados de enfermagem no ambiente aeroespacial à pacientes traumatizados: cuidados durante e após o voo. Texto Contexto Enferm [online]. 2011 Jul-Set [acesso 2014 Jun 14]; 20(3). Disponível em: http:/ / www.scielo.br/ pdf/tce/v20n3/08.pdf

10. Silva SG, Nascimento ERP, Salles RK. Bundle to prevent ventilator-associated pneumonia: a collective construction. Texto Contexto Enferm [online]. 2012 Out-Dez [acesso 2014 Jun 29]; 21(4). Disponível em: http://www.scielo.br/pdf/tce/v21n4/en_14.pdf

11. Medeiros GO, Souza LM. Proposta de criação de protocolo de enfermagem para o cuidado de pacientes com abscesso de parede pós-cesária. Rev Ciências Saúde. 2010 Jan-Mar; 21(1):1-20.

12. Trentini M, Paim L. Pesquisa convergente-assistencial: um desenho que une o fazer e o pensar na prática assistencial em saúde-enfermagem. $2^{\mathrm{a}}$ ed. Florianópolis (SC): Insular; 2004.

13. Melnyk BM, Fineout-Overholt E. Evidence-based practice in nursing \& healthcare. A guide to best practice. 2a ed. Philadelphia (US): Lippincot Williams \& Wilkins; 2011.

14. Morse JM, Field PA. Qualitative research methods for health professionals. 2a ed. London (UK): Sage, 1995.

15. Ministério da Saúde (BR); Conselho Nacional de Saúde. Resolução 466, de 12 de dezembro de 2012. Dispõe sobre as diretrizes e normas regulamentadoras de pesquisas envolvendo seres humanos [Internet]. Brasília; 2012 [citado 2014 Jun30]. Disponível em: http:/ / conselho.saude.gov.br/resolucoes/2012/ Reso466.pdf

16. The National Cancer Institute. Common Terminology Criteria for Adverse Events v4.0 [Internet]. 2009 [acesso 2013 Dez 10]. Disponível em: http:/ / evs.nci.nih.gov/ ftp1/CTCAE/CTCAE_4.03_QuickReference_5x7.pdf.

17. Paice JA, Ferrell B. The management of cancer pain. CA Cancer J Clin. 2011May-Jun; 61(3):157-82.

18. Sonis ST. New thoughts on the initiation of mucositis. Oral Dis. 2010 May; 16:597-600.

19. Schirmer EM, Ferrari A, Trindade LCT. Evolução da mucosite oral após intervenção nutricional em pacientes oncológicos no serviço de cuidados 
paliativos. Rev Dor. 2012 Abr-Jun; 13(2):141-6.

20. Peterson DE, Lalla RV: Oral mucositis: the new paradigms. Curr Opin Oncol. 2010 Jun; 22(4):318-22.

21. Peterson DE, Ohrn K, Bowen J, Fliedner M, Lees J, Loprinzi C, et al. Systematic review of oral cryotherapy for management of oral mucositis caused by cancer therapy. Support Care Cancer. 2013 Jan; 21:327-32.

22. Gautam AP, Fernandes DJ, Vidyasagar MS, Maiya AG, Vadhiraja BM. Low level laser therapy for concurrent chemoradiotherapy induced oral mucositis in head and neck cancer patients - a triple blinded randomized controlled trial. Radiother Oncol. 2012 Aug; 104(3):349-54.
23. Barasch A, Elad S, Altman A, Damato K, Epstein J. Antimicrobials, mucosal coating agents, anesthetics, analgesics, and nutritional supplements for alimentary tract mucositis. Support Care Cancer. 2006 Jun; 14(6):528-32.

24. Brito CA, Araújo DS, Granja JG, Souza SM, Lima MAG, Oliveira MC. Efeito da clorexidina e do laser de baixa potência na prevenção e no tratamento da mucosite oral. Rev Odontol UNESP. 2012 Jul-Ago; 41(4):236-41.

25. Yarom N, Ariyawardana A, Hovan A, Barasch A, Jarvis V, Jensen SB, et al. Systematic review of natural agents for the management of oral mucositis in cancer patients. Support Care Cancer. 2013 Nov; 21(11):3209-21. 